\title{
Information Dissemination Needs of Indonesian Migrant Domestic Workers in Malaysia
}

\author{
Graham Orange ${ }^{1}$, Verena Seitz ${ }^{2}$ and Ah Lian Kor ${ }^{1}$ \\ ${ }^{1}$ Leeds Metropolitan University, Leeds, United Kingdom \\ ${ }^{2}$ Neu-Ulm University of Applied Sciences, Neu-Ulm, Germany
}

\begin{abstract}
Substantial numbers of Indonesian women are seeking employment as domestic workers in Malaysia in order to escape poverty and unemployment and to be able to support their families back home. Most Indonesian domestic workers in Malaysia face unpleasant working conditions with long working hours and no freedom to move or communicate; some find themselves in a situation of abuse. In many cases, the decision to work abroad is made without being properly informed about what to expect. Furthermore, most of the Indonesian migrant domestic workers do not know about process and procedures and are not aware of their rights and the possibilities of seeking assistance when problems occur. In order to empower the target group, relevant information need to be disseminated. Current strategies do not seem to achieve the desired effect. Many of the affected women come from remote areas, are poor and have a low level of education; therefore, their skills to make use of written or even digital information are limited. Appropriate strategies are suggested to utilise traditional and commonly used information dissemination channels such as cultural performances, group discussions and radio. Educational measures should be combined with aspects of local entertainment culture in order to attract attention and to provoke identification with the issues discussed. Further research is necessary to actually develop an appropriate information dissemination strategy with regard to the target group and to evaluate its benefits by conducting pilot projects.
\end{abstract}

Keywords: knowledge, information, dissemination, Indonesia, Malaysia, domestic worker

\section{Introduction}

Malaysia's rapid economic growth, the resultant higher standard of living and the increasingly common intention of Malaysian women to follow their own career aspirations have increased the demand of employing a domestic worker which will take over the household chores and take care of the children and elderly.

Approximately 320,000 foreign domestic workers are registered with the Malaysian government of which around $96 \%$ come from Indonesia (ILO, 2006; MFA, 2006; Al Jazeera, 2010). These women work abroad because their chances of finding work in their home region, and the wages they could earn, are very low. Working abroad for a few years gives them the possibility to support their families in their home country by sending back money.

Unfortunately, their perception of life and work in Malaysia does not match the reality. Indonesian domestic workers in Malaysia face a range of problems, some of which start from the moment of being recruited in their native villages. Complex recruitment practices, accumulated debt, no possibilities to cancel the agreement once recruited, unpleasant working 
conditions, no communication possibilities and abusive employer behaviour are common problems (Davadason, 2011).

The main reason, as identified by researchers and organizations working in the field, for why Indonesian women are vulnerable to mistreatment and exploitation is because of a lack of knowledge and information. Indeed, the International Labour organization recognised this (ILO, 2008) and listed brief requirements. However, no research has been conducted so far on how to develop an appropriate knowledge and information dissemination strategy especially tailored to the needs and challenges of this target group.

This paper is based on a research undertaken in 2008. The primary research was conducted using interviews and observations of the stakeholders identified in this paper. Field work was carried out in Indonesia and Malaysia over a period of approximately 12 months.

\section{Important Stakeholders}

The major groups involved in the migrant worker system are the governments, domestic workers, sponsors, recruitment and employment agencies and employers. All these parties are stakeholders in the profitable foreign domestic worker business, each of them having something to lose (Anggraeni, 2006).

\section{Governments}

The government of the Republic of Indonesia has two potentially conflicting interests. First, it is responsible for legislation concerning migrant workers' issues and protection of their citizens, second, the government has to pursue the country's economic interests (Anggraeni, 2006). According to the International Labour Organization (ILO), the remittances being brought back home by Indonesian migrant workers were $\$ 8.2$ billion in the year 2008, an amount increasing each year (ILO; 2008).
One of the main benefits for Malaysia receiving foreign domestic workers is that these workers fill positions which the local population does not want. Local women are not interested in these jobs mainly because of very low salaries and unfavourable working conditions (UNFPA, 2006; Kaur, 2004).

\section{Migrant Workers}

When Indonesian women are asked why they decided to work as domestic workers in Malaysia, they mostly answer with 'money'. Scarcity of work in their local surroundings, low income in the informal sector and having a family to take care of are the main reasons for women to leave their families and seek work overseas (Anggraeni, 2006). Malaysia is a popular destination because it is close to Indonesia; in terms of geography, culture and language. According to Malaysian Immigration Law, a foreign domestic worker must be female and between 21 and 45 years old (Immigration Department of Malaysia, 2010); however, according to primary data given by the Women's Aid Organization (WAO, 2008), a Malaysian Non-Governmental Organization (NGO) committed to confronting violence against women, many of the Indonesian domestic workers have a falsified date of birth in their passport.

\section{Recruiters or Sponsors}

The recruiters in the villages are called 'sponsors'. They not only recruit the women, organize the important documents for them and send them to the recruitment agency in the big city, but in most cases these recruiters act as 'sponsors'. Sponsorship includes payment of the fees to get the necessary documents. The fees are for the medical check and the expenses to travel to the recruitment agencies, where the training and placement will be conducted. 
In this context, sponsoring means that the money will be lent to the women, who mostly come from impoverished families and could not afford to bear these initial expenditures. In many cases, these sponsors are women who formerly worked as migrant domestic workers. Often they recruit candidates for the recruitment agencies which had sent them overseas (Anggraeni, 2006).

\section{Agencies}

There are two types of agencies. Firstly, there are recruitment agencies in Indonesia. They started sending workers overseas in the late 1970s. In 2007, there were 455 registered agencies listed (Nainggolan, 2007). Secondly, there are the employment agencies in Malaysia. They work together with one or more recruitment agencies in Indonesia and pay them a recruiting fee of $\$ 480$ for each domestic worker supplied. It is their task to place the women.

\section{Employers}

Employers in Malaysia are mostly middle class people. In order to be entitled to employ a domestic worker, the employer must have children or parents who need care. Furthermore, the employer and his or her spouse must be working and their monthly minimum household income must be $\$ 980$ (Tenaganita, 2008; Immigration Department of Malaysia, 2010).

\section{Information Needs throughout the Migration Process}

\section{Overview of the Migration Process}

Usually, women in their villages are contacted by a sponsor. Once the women agree to work overseas, the necessary documents have to be organized, which is mostly done with the help of the sponsor. Since the prospective migrant workers most probably come from poor families, the sponsor often pays the fees for the documents as well as the ticket to travel to the recruitment agency which might be far away from their native villages. Later, the wages of the first five or six months will be withheld to pay back their debts (Raharto, 2002; HRW, 2004).

At the recruitment agency, the prospective migrant workers are trained in housekeeping, childcare and language skills. On completion of training, the candidate has to pass a competency test. Only then, the agency will help the women to apply for a passport, request a temporary employment visa and obtain approval from the Ministry of Manpower and Transmigration. The candidates have to wait to be selected for employment by a Malaysian agency. Most of the women seem to be told that they will stay for one month with the recruitment agency, but it can be up to eight months (HRW, 2004; PDOP, 2008).

On arrival in Malaysia, the women are picked up by their Malaysian agent. Some of the employment agencies offer orientation programs, others place the worker with the employer on the same day they arrive in the country. The domestic workers will usually work for two years for the employer in Malaysia and then go back home.

\section{Needs of Migrant Domestic Workers}

A study on information needs of Indonesian migrant workers conducted in Indonesia in 1999 reveals that causes for problems occurring are, amongst others, the low level of knowledge and skills of the prospective migrant workers themselves and the fact that the information they are given is generally neither accurate, comprehensive nor appropriate. The consequence is that the prospective migrant worker becomes either directly or indirectly an object of commercialisation (Romdiati, Noveria and Bandiyono, 2002).

\section{Needs before Departure}

The recruitment practices in Indonesia have been criticised by various sources (Anggraeni, 2006; Raharto, 2002; HRW, 2004; Romdiati, Noveria and Bandiyono, 2002; ILO, 2006; WAO, 2008 and Tenaganita, 2008). One major problem is that the information given by the sponsors 
paint a picture of the employment situation that is very different from the reality.

The common practice of the local recruiters is to promise the women high wages, while describing the work as easy.

Officers of Tenaganita, a Malaysian NGO committed to protecting the rights of women and migrants, explained that sponsors have their ways of 'influencing a young girl's mind'. NGOs in Indonesia have campaigned against Indonesian women going to Malaysia seeking work. So the agents target increasingly younger girls at the remotest places 'where the people have no idea' (Tenaganita, 2008).

WAO states that the sending country is responsible for providing comprehensive information to be given to the prospective domestic workers sent to Malaysia. In order to do so, a proper orientation program is essential. However, domestic workers coming from Indonesia seem not to know much. They are only taught 'how to obey and respect their boss', instead of learning about their rights. Most of the workers who need the intervention of WAO 'don't know anything'. They do not know that they should get their wages every month, they do not know that the employer should not keep their passport, they do not have a copy of their employment contract, they do not know their agency's telephone number, they do not know to whom to go for help and most crucially they do not know that they deserve help and have the right to call for help (WAO, 2008).

Lack of knowledge of the migrant workers gives rise to the following essential information needs prior to departure:

- how to ensure proper legal process including: ensuring that the sponsor and the agencies are legal and proper legal documents are obtained, including passport and visa;

- duration and costs of recruitment process;

- what to expect during employment, including: working conditions such as tasks, working hours, day/s off, amount of monthly wages, deductions, payment of wages, possibilities to move and communicate;

- employment contract which includes rights and responsibilities;

- actions to take and where to seek assistance if the rights are not protected and/or in case of abuse.

\section{Needs during Employment}

Indonesian domestic workers are very restricted in their movements and highly controlled by their employer, therefore they have 'absolutely no access to information' while they are in Malaysia. Furthermore, many of the domestic workers who brought informative material are not allowed to keep it, for it will be taken away from them by their agency or employer. Even if they are equipped with information, it is often impossible for them to make use of it because they are not allowed to make phone calls, leave the house alone or communicate with others (WAO, 2008; Tenaganita, 2008).

In addition to the domestic workers' need for information and communication, there is a need for an improved exchange of information among the employment agencies in Malaysia. It seems that they do not share their information about abusive employers with each other. Therefore, employers who might be blacklisted with one agency might still be able to get a 'maid' from another agency.

The information and knowledge needs during employment are as follows:

- worker's rights,

- possibilities to end the contract before time,

- that she is not the only person facing such problems,

- that there are people out there who are willing and able to help, 
- what to do or where to go to find help,

- how to travel back home,

- how to bring the wages back home safely.

\section{Needs on Return}

Returning migrant workers face their first difficulty when they arrive at the airport in Jakarta. There they will be led to a special terminal for returning migrant workers by following the sign 'Jalur khusus TKI' (which means: 'Special lane for Indonesian migrant workers'). The returning migrant workers are subjected to extortion by airport employees, immigration, customs and transport operators. Illegal fees are demanded and poor currency exchange rates offered. This terminal is known as 'collect toll' (HRW, 2004; ADB, 2006; Anggraeni, 2006).

According to Wawa (2005), returning Indonesian migrant workers are not treated with respect. The Indonesian workers who do not understand the situation in the airport are not given the right directive. On the contrary, they are targeted for exploitation. Therefore, those Indonesian migrant workers who have knowledge about this problem avoid arriving in Jakarta when going home to their family.

The knowledge required on return can be summarised as follows:

- potential problems with authorities,

- potential problems with relatives, friends and members of the community,

- training how to handle interpersonal problems,

- development of skills on how to manage finances and how to run a business.

\section{Issues to Take in Account When Developing a Knowledge and Information Dissemination Strategy}

Before developing a new information dissemination strategy, it is important to consider potential challenges for the usefulness of channels and methods since they might form obstacles for a successful and sustainable implementation of a strategy.

\section{Finance}

The financial background of the prospective migrant worker determines the extent to which they can afford to travel, to buy books or to go to an Internet Cafe. Therefore, it co-determines their chances to gain information.

The majority of the migrants come from poor areas, many of them from remote rural regions (Kaur, 2004; Lyons, 2005). They have little income, barely any savings and have chosen to leave their families and work overseas because they hope for a better life. The recruitment system does not require the prospective migrant worker to spend any money in the first place, but to pay back at a later stage, which reduces the entry barriers to this kind of work. At the same time, the debts accumulated from the moment the decision is made make it impossible for the women to change their mind at a later stage.

\section{Education}

The level of education determines the knowledge and the skills a prospective migrant worker posses to make use of information, her ability to read and write, to understand complex correlations, to calculate costs and to operate technological devices to access information. Therefore, the level of education co-determines her chances to gain information and her ability to enhance personal knowledge.

The poor find themselves trapped in a cycle of poverty. Since they are poor, the families cannot afford to send their children to school, but need them to work in order to support the family. Due to the resulting lack of education, the income opportunities of the children remain limited and therefore their chances to escape poverty and to improve their longterm livelihoods remain limited. The poor do not have many chances to escape this 
vicious circle. Working overseas can be one way of achieving a sustained improvement of their living conditions; however, poverty and a lack of education may not only be a catalyst for seeking employment abroad, but it may also pose obstacles for a smooth process. A lack of skills and knowledge might cause problems before departure, during employment and on return.

\section{Cultural Mindset}

Cultural values and norms can influence the ways knowledge is obtained and disseminated and the level of importance assigned to information and knowledge in general. Furthermore, the cultural mindset might impose barriers to knowledge flow.

One major problem is the low willingness to share information. This 'poor information culture' (Depkominfo, 2002) is strongly connected with the hierarchical thinking in the Malay world. Seniority, power and status are important for the members of the society. According to a study into national cultural differences conducted by Geert Hofstede in the 1980s, Indonesia and Malaysia score high in power distance index. Power Distance Index (PDI) is "the extent to which the less powerful members of institutions and organizations within a country expect and accept that power is distributed unequally." (Hofstede, 1997, p. 28). The high PDI "is indicative of a high level of inequality of power and wealth within the society. This condition is not necessarily forced upon the population, but rather accepted by the society as part of their cultural heritage." (Itim, 2008).

Malays as well as Indonesians might not perceive the need to require information for decision-making to the same extent as Westerners might perceive this need.

When developing a strategy to disseminate information, it is important to decide on the appropriate channels. Therefore, it is important to understand the traditional and common ways to share information.

'In the Malay community, knowledge [...] is often passed down orally. The problem with oral transmission of knowledge is that, the bulk of the message or lessons would usually get lost with time. [...] This method of transmission is attributed to the lack of emphasis on the importance of reading and writing in the traditional Malay community of the past. There was little knowledge which was passed down in the form of writing for mass distribution in the community. [...] Much of education, especially non-religious was not accorded with any degree of importance. [...] The instruction of knowledge was to trusted individuals only.' (Zamani, 2002, pp. 260261)

Indonesia and Malaysia are not reading cultures (Stephenson, 1996; Zamani, 2002). When entering a book store in Indonesia or Malaysia, it is noticeable that even the countries' largest ones seem to have fewer books to sell than an average book store in a European big city. The variety of publications in Bahasa Indonesia or Bahasa Melayu (official languages of Indonesia and Malaysia) is little; the majority of the books, especially in Malaysia, are published in English. Furthermore, books are comparably expensive.

A survey conducted in 1996 revealed the reading habits of the average Malaysian:

- spends less than 30 minutes a week reading newspapers;

- spends less than two hours a week on reading magazines, books and comics;

- reads about two books a year;

- 65 percent of the respondents were never read to during their childhood. (Zamani, 2002) 
The fact that reading and writing are not regarded as being of great importance might have several reasons. Indonesia and Malaysia are collectivist cultures, with a strong emphasis on the group rather than on the individual (Hofstede, 1997). Doing things in the group, such as sitting together and talking instead of "hiding" behind a book might be more favourable socially. Besides that, knowledge should not be passed to the masses, but to trusted individuals only. By publishing information and knowledge in books, one loses control over who will gain the knowledge. Another reason is simply that many people cannot afford to buy books. "Village folks lack knowledge because most lack money to buy reading material." (Zamani, 2002, p. 361) Poverty, education and reading culture seem to be closely linked.

\section{Digital Divide}

Information and communication technologies (ICTs) cannot in themselves transmit knowledge but they can facilitate its dissemination and sharing, therefore it is necessary to evaluate the availability of ICT for the target group as well as their skills to use this technology and their ability to afford owning or using it.

ICT includes fixed line telephones, mobile phones, radios, televisions, computers and internet access. These devices increasingly affect how we work and connect with each other, with whom we connect and how we make decisions, based on which information (Servon, 2002).

'The digital divide refers to the uneven distribution of information and communication technology (ICT) between and within nations.' (Evers and Gerke, 2005, p. 7)

The concept of the digital divide goes beyond the merely technological aspect. In this sense, digital divide describes

'the gap that exists in most countries between those with ready access to the tools of information and communication technologies, and the knowledge that they provide access to, and those without such access or skills. This may be because of socio-economic factors, geographical factors, educational, attitudinal and generational factors, or it may be through physical disabilities.' (Cullen, 2001, p. 311).

These socio-economic factors may lead to a situation where certain segments of society do not have equal possibilities to gain or contribute information or knowledge and to derive benefits there from. The underserved sectors, or 'have nots' in terms of access to ICT are mainly elderly, youth, poor, rural, women and disabled. Prevailing obstacles to making use of ICT 'include high rate of illiteracy, unawareness of the relevance of information, poverty and lack of infrastructural facilities.' (Aguolu, 1997, p. 25).

Indonesia is the world's largest archipelagic state. Due to its large geographical area and high diversity, there are vast differences in ICT penetration between urban and rural areas as well as between rural areas on Java and rural areas at remote islands. Around $57 \%$ of the population live in rural areas (ADB, 2007). Considering that Indonesia has a population of 238 million, the number living in rural areas and therefore the number of people being affected by an insufficient ICT infrastructure is immense. Indeed, Indonesia has the lowest level of internet penetration in Southeast Asia (Jakarta Post, 2011).

Around $65 \%$ of the rural areas in Indonesia have mobile networks coverage, but only $23 \%$ of the villages have cables for fixed line phones (BPPT, 2007).

Radio and television (TV) remain very important information dissemination channels. $96 \%$ of the urban districts and $68 \%$ of the rural districts are covered by TV signals. In 2004, almost half of the Indonesian households owned a radio and TV (BPPT, 2007).

Even if not all of the households are equipped with radio or TV, people gather and share the experience within the neighbourhood. In order to reach the remotest islands, messages can be sent 
over the radio to keep family members informed.

\section{Communication}

The Indonesian National Body for Placement and Protection of Indonesian Workers (BNP2TKI) publishes lists of problems encountered and reported by Indonesian migrant workers. For the period from January to April 2008, the most frequent complaint was the cutting off of any communication possibilities (BNP2TKI, 2008).

The majority of Indonesian domestic workers in Malaysia are not allowed to make calls back home, not allowed to communicate and socialize with other Indonesian migrant workers and often not even able to communicate with the employers. These rules are due to hierarchical differences but also due to a lack of trust. A guidebook for Singaporean employers gives the advice: "You can also discern whether she is a potential troublemaker if she asks questions such as [...] 'Can I use a mobile phone or have a phone in my room?"' (Whatt, 2004, p. 45).

One of the prospective domestic workers, interviewed as part of this research, explained that on her way to Malaysia she encountered this problem. However, she did not complain about it and only described the situation after being asked specifically about this topic. She owned a mobile phone, however, her sponsor told her straight away that she will not be allowed to take it with her to Malaysia, so she left it at home. Whilst she was in Jakarta for two months, to be trained and get her documents organized, the recruitment agency didn't allow her or the other prospective domestic workers to call home. They were told that they would not be allowed to call their families for at least the first six months of their employment in Malaysia. After that time, it depends on the employer if they can call home. Mostly, domestic workers aren't allowed to call home for one year. When asked if she knew the reason for these rules, she answered 'no'. Her family knows about her plans to work in Malaysia, but they don't know where in Malaysia she will be.

Once Indonesian domestic workers are with their employers, they are not able to gain information by themselves and they are very difficult to be reached by any information dissemination initiative. If the prospective migrant worker is going through the proper channels and has a responsible recruitment agency, she might be able to get useful information during the recruitment process; however, in order to ensure that the worker has access to the legal channels of employment and to empower the woman in her decisionmaking process from the very beginning, it is suggested that the best moment to reach the prospective migrant worker is before her departure from her home town or village.

\section{Analysis of Knowledge and Information Dissemination Strategies and Development of Recommendations}

Information has been identified as being important for Indonesian migrant domestic workers. Information is needed for decision-making, knowing ones rights and responsibilities, acquiring skills and knowing what to expect including potential problems. This section looks at some of the communication channels currently being used and suggests others that have the potential to make a significant contribution.

Information can be disseminated by various channels and methods:

- word of mouth: discussion, speech;

- print media: book, newspaper, magazine, brochure, poster, leaflet;

- ICT: telephone, radio, television, Internet.

As discussed, not all channels and methods are equally available and appropriate to all interest groups, depending on their area of origin and its specific infrastructure, financial capacity, education, cultural barriers and so on. 
In other words, affordability, availability and the skills to make use of the respective channel are important issues to be considered.

\section{Analysis of Current Strategies}

The Internet is becoming increasingly popular. At relatively low costs, information can be disseminated and retrieved quickly while being accessible worldwide. Therefore, information disseminated over the Internet has the potential to reach many people. However, as a result of the digital divide, it is unlikely that poor women, mostly from rural areas, have the opportunity or the skills to access any online information. Despite this, there are authorities, organizations and initiatives concerned with Indonesian migrant workers' issues that are making use of the Internet. Some examples are: the websites of the National Body for Placement and Protection of Indonesian Workers and the Indonesian Embassy in Kuala Lumpur, lists of recruitment or employment agencies presented at websites of local governments in Indonesia or at the website of the Malaysian Association of Foreign Maid Agencies, a group for alternative media which created a website especially for Indonesian migrant workers in Korea, as well as innovative forms like the use of social networking platforms by the Union for Indonesian Migrant Workers, the use of online Web journals (Weblogs), or of online platforms to watch and share videos.

Print media, including books, brochures or booklets and leaflets, some given out for free, and some to be purchased, are widely available. The focus is on information material for prospective migrant workers, offering guidelines about working conditions, the migration process and assistance available; however, the inadequate distribution and the nonreading culture of the migrant workers impacts on their effectiveness. Some organizations, such as Tenaganita, distribute leaflets and credit card sized cards with helpful information and actionline contact numbers. These are distributed to the media and at conferences and are designed to inform the general public of the situation so that concerned neighbours of employers of domestic workers can contact appropriate authorities.

In the main, prospective domestic workers neither have the opportunity to access information presented on the Internet nor to get hold of printed media, except for a booklet distributed during the predeparture training a few days before leaving Indonesia; therefore, oral dissemination of information is of special importance. In this context, radio and TV are categorized under oral dissemination strategies, although they make use of technology; however, this technology is accessible for a large portion of the population. Even though around only 50 percent of the households are equipped with a radio or $\mathrm{TV}$, people gather and share the experience within the neighbourhood. For example, in one of the villages in the study, around 30 people gather in the evenings to watch TV in the house of a neighbour.

Several initiatives in Indonesia and other countries are already undertaken by local communities to broadcast their own radio program. The aim of these community radios is to pursue the interests of the community, to broadcast local news, to inform about local events or to share local culture. The benefits of these programs are that local communities have the possibility to empower themselves by sharing information, and strengthen their unity by sharing common interests and by using the local language (Nasir, Tanesia, Prakoso and Amri, 2007).

"Community radio is a social process or event in which members of the community associate together to design programmes and produce and air them, thus taking on the primary role of actors in their own destiny, whether this be for something as common as mending fences in the neighbourhood, or a community-wide campaign on how to use clean water and keep it clean, or agitation for the election of new leaders. The emphasis is on the ownership of democratic and development efforts by the members of the community 
themselves and the use of media, in this case radio, to achieve it. In every sense, this is participatory communication (not programmes made about them by somebody else!)." (Fraser and Estrada, 2001, p. 1)

Other than TV and radio, there are other key channels of oral communication of information including sponsors and employment agencies. Potential domestic workers, because of their lack of access to information, are dependent on what they are being told by sponsors or on a predeparture program offered by agencies, however, there is a problem of conflicting interests and resultant reliability of information provided this way. Further sources for oral information might be family members and friends who already have experience with working overseas.

Some returned migrant domestic workers are now working together with NGOs to share their experiences with prospective migrant workers or to organize a supporting infrastructure. One of them is Nirmala Bonat, a young Indonesian woman whose case became famous because of the severity of her abuse during her employment in Kuala Lumpur. She was willing to share her plight in a TV documentary and initiated the DW Action Line (Domestic Worker Action Line) at Tenaganita (Tenaganita, 2008). Other returned domestic migrant workers, such as Sri Suryani, became active in the Union for Indonesian Migrant Workers (SBMI). Sri explained her intention: "I am telling my own story, but many people have the same experiences. I want to help them to ease their burden, so they don't feel helpless and overwhelmed. They need to move on from their experiences. I hope others don't have the same experiences." (Tenaganita, 2005).

\section{Alternative Dissemination Strategies}

Some of the following ideas are taken from experiences of other target groups, in other countries or within other contexts and some combine modern and traditional forms of information dissemination.
The first is an example from Malaysia which demonstrates that it is feasible to connect remote villages to the World Wide Web: the e-Bario project. The village of Bario is located in the Kelabit Highlands in Sarawak on the island of Borneo, not far from the Indonesian border. It is a highly isolated and remote place. Since Bario is not accessible by road, prior to the possibility of flying there, the inhabitants had to walk far through the jungle, climb mountains, cross rivers and valleys for several weeks in order to reach the next town. 93 percent of the 1,000 community members are farmers (ESCAP, 2006; UNIMAS, 2005).

The community was "a real case of digital divide and digital poverty" (UNIMAS, 2005); isolated and remote location, no telecommunication service, electricity generated by solar energy or generators. Therefore, and for the community's readiness to participate, the research team from University Malaysia Sarawak (UNIMAS) chose Bario for their research project to determine opportunities for social development available from the deployment of ICT within remote communities in Sarawak. The achievements of the project were as follows:

- establishment of a community telecentre with ten computers, printers, a copier and a fax machine;

- installation of four VSAT satellite dishes and equipment, which are now providing a satellite communications link to the telecentre and the school;

- establishment of six public telephone booths, which have a great impact on the community's means to communicate with members of the community residing outside Bario and therefore have eased information flow in and out of Bario. 
The major benefits of the project are in the areas of education and commerce. With the community's access to ICT, there is an increased computer literacy among the students, teachers and the community.

Furthermore, the members of the community are able to communicate with the rest of the world using telephones and the Internet. The members of the community who are involved in tourism have taken advantage of the ICT by being able to communicate with potential tourists directly via email, and confirm accommodation bookings online. Since then, there have been more tourists flying to Bario. The number of flights was increased from one to two flights per day. One of the consequences is a reduction in rural-urban migration: more youths and their families are staying back in Bario running the tourist accommodation and tourist activities (ESCAP, 2006).

However, the case above is a very high cost initiative and most of the solutions required to meet the short term needs of Indonesian migrant workers are likely to be low budget and low technology. To this end, TV and radio have already been discussed as appropriate technologies and current information dissemination strategies show that several initiatives by local communities already exist to set up their own radio program, which amongst other topics informs of migrant workers issues or offers a communication channel between migrant workers and their families.

An approach to disseminate information in rural areas which involves the community closely is that of performing street dramas, role plays or sketch shows. Tamil Nadu Women's Forum in India is known for this form of community awareness programs. A group of people tour from one village to the other. In the villages, they target places where people usually meet and start playing music in order to attract attention. The drama and music is designed and written to inform of key issues, for example about women's rights. The women in the village are encouraged to participate in singing, dancing and playing drums. Most importantly, after the drama has been performed, there will be a discussion initiated where the women can ask questions. The aim is to disseminate the most basic information about the issue and hence to trigger curiosity to know more about it. Once the curiosity is triggered, it is assumed that the women will try to find out more information by themselves.

A further example of community awareness programs is a cultural mela (South Asia: congregation, large gathering) performed in the scope of a project to fight bonded labour in India, supported by Asha for Education. A cultural team comprising 15 released bonded labourers and 15 members of staff, all of them belonging to the same tribe as the target audience, conducted campaign work in affected villages. The program includes street drama, role-plays and bonded labour issue based songs. Posters, pamphlet and texts of laws regarding wages are distributed. The cultural mela is an effective method of reaching the people, especially with regard to the high illiteracy of the target people. As the members of the cultural team belong to the same tribe, they were able to reach the community well and to effectively convey the ideas (Asha, 2008).

An alternative to the street drama is the shadow puppet play; this traditional play does not only entertain but also informs of current issues and discusses them controversially by making use of different puppet characters. Shadow puppet plays (wayang kulit) have a long tradition in Indonesia and also play a role in daily life. For traditional Indonesians, a shadow play is an image of the cosmic and political conditions. The communist party, pre 1965, used shadow plays to propagate their ideologies. Today, the Indonesian government uses the play to campaign family planning (Werning and Fuhrmann, 2008).

\section{Recommendations}

Many of the available information distribution channels such as word of mouth, print media and ICT have already been discussed in this section. Here, 
appropriate approaches to dissemination which should prove successful in informing potential migrant workers of pitfalls and their rights have been identified.

The advantages of ICT and print media are that information can be shared with many people and the content will be the same for everybody. However, they depend very much on their availability, on the target group's possibilities to afford buying or using them and on their perceived need to do so. This poses a significant hurdle with respect to prospective migrant domestic workers in Indonesia. The penetration of television and especially radio is higher than that of other information and communication technologies and many of the remote areas can be reached by making use of this technology. Listening to the radio and watching television are usual activities; therefore there are no cultural obstacles for doing so. Community radio programs allow the possibility of gaining the listeners' special attention by using the local language or dialect and broadcasting local music and information. Oral, face-toface information dissemination, seeming culturally more valuable in collectivist cultures, has the potential to involve the target group directly, creates a group experience, triggers curiosity and generates interest in the issues under discussion; however, it is more time consuming and expensive for the informant and reaches only selected groups of people.

Although the Internet has been identified as one of the less appropriate channels with respect to the target group, some recommendations for improving current practices should be made. Website navigation of the respective governmental authorities should be intuitive and available in the Indonesian language. It should be government policy to connect more rural regions to the Internet and to offer the services at affordable prices, free where appropriate, and provide training.

Print media should be easily understandable. The lack of reading culture will have an impact on the design of reading material. One possibility is the use of comic strip format providing story lines that the reader can associate with. Furthermore, sophisticated reading skills are not required.

Migrant workers' issues discussed on TV should not only be presented in the form of news or documentary, but also in the form of short TV spots, TV series and serials and movies which are entertaining and simultaneously raise awareness of issues.

Similarly, community radio programs should broadcast entertaining radio dramas which create awareness of the situation of migrant domestic workers. Process, procedures and rights should be explained as part of the story. Information disseminated in the form of a radio drama may trigger more attention and curiosity than news or documentaries.

Street plays would be an appropriate way to raise awareness and to disseminate information amongst the Indonesian poor. The theatrical team should be a group of peers consisting of returned migrant domestic workers accompanied by social workers. The involvement of community leaders such as region heads, religious leaders and teachers demonstrates commitment.

Puppet shows, for example shadow puppet plays, are a traditional form of entertainment. These not only entertain but also inform of current issues and discuss them controversially by making use of different puppet characters. Shadow puppet plays have a long tradition in Indonesia, play a role in daily life and have long been used to support campaigns.

\section{Conclusion}

This paper discusses the information needs of Indonesian migrant domestic workers, their challenges to gain information and different strategies of information dissemination. The aim is to establish understanding that being informed can considerably improve the well-being of the target group and to develop a set of recommendations for creating information dissemination strategies which are more appropriate considering the particular challenges faced. 
The research identifies the major stakeholders in the migration process: the governments of Indonesia and Malaysia, the domestic workers and their families, the sponsors, the agencies and the employers. It is clear that for some of these stakeholders there are particular and often conflicting interests.

Knowledge and information needs of Indonesian domestic workers at different stages of the migration process have been identified.

Problematic issues before departure, during employment and on return are equally important for the target group. In summary these needs are necessary to:

- enable informed decision-making,

- inform about rights and responsibilities,

- prevent human trafficking,

- prepare for what to expect,

- inform where to get help,

- acquire skills,

- empower the target group.

Importantly, aspects for developing an appropriate dissemination strategy have been evaluated. The paper sets out to inform information providers of the special challenges faced by the target group, such as lacking financial resources, skills and infrastructure as well as a certain cultural mindset which might pose obstacles for the successful and sustainable implementation of strategies.

Current information dissemination strategies have been analyzed with regard to how appropriate they are to inform the target group effectively and alternative strategies have been suggested.

It can be concluded that efforts to reach the target group at an early stage should be increased. Information concerning process, procedures and rights should become more transparent and should be more easily accessible. An increased number of community telecentres in rural areas which offer ICT services and training of skills to use the technology for low or no fees could be one useful way to empower rural women. However, it is considered to be culturally more appropriate and therefore more efficient, at least in the short run, to visit the women in their native villages and to create group experiences. A combination of different strategies such as combining aspects of group experience, entertainment and education is a way forward that is proven and culturally acceptable.

\section{Further Research}

Throughout the period of study, many areas for research have been identified which were outside the scope of this project. Opportunities for further research are:

- investigation and evaluation of initiatives and campaigns done by Indonesian NGOs and other initiators in order to gather more information about material available and experiences made and to assess their effectiveness;

- conducting more interviews with Indonesian migrant domestic workers, prospective as well as returned ones, with the public in general, NGOs, authorities and other interest groups concerning the perceived need of gaining and sharing information, the level of being informed and the possibilities to appropriately disseminate information;

- development of an information dissemination strategy according to the insights gained;

- running pilot projects in different villages and evaluate their benefits and costs.

\section{References}

ADB (2006). "Indonesia: Country Gender Assessment," Manila: Asian Development Bank, [Online], [Retrieved February 16, 2008], 
http://www.adb.org/Documents/Reports/ Country-Gender-Assessments/cga-ino.pdf. ADB (2007). "Key Indicators 2007: Inequality in Asia - Indonesia," [Online], [Retrieved August 18, 2008], http://www.adb.org/Documents/Books/K ey_Indicators/2007/default.asp.

Aguolu, I. E. (1997)."Accessibility of Information: a Myth for Developing Countries?" in New Library World, Vol. 98, No. 1132, 25-29.

Al Jazeera (2010). "101 East episode: Maid in Malaysia, "Broadcast 02 December 2010 [Online], [Retrieved February 02, 2011], http://english.aljazeera.net/programmes/ 101east/2010/12/201012111381477367 7.html.

Anggraeni, D. (2006). Dreamseekers, Indonesian Women as Domestic Workers in Asia, Jakarta: International Labour Organization.

Asha (2008). 'Bonded Labour' [Online], [Accessed 19 August 2008], www.ashanet.org/projects new/documents/591/Bonded_Labour_Rep ort.doc.

BNP2TKI (2008). "Kasus Permasalahan TKI Januari Sampai April 2008," [Online], [Retrieved July 20, 2008], http://www.bnp2tki.go.id/content/view/1 90/88/.

BPPT (2007). 'Indikator TIK. Edisi 2007, Seri TIKoMeter,' Jakarta: Badan Pengkajian dan Penerapan Teknologi, Pusat Teknologi Informasi dan Komunikasi, [Online], [Retrieved August 23, 2008], http://tikometer.or.id/index.php?option=c om_content\&task=category\&sectionid=1\&i $\mathrm{d}=13$ \&Itemid $=2$.

Cullen, R. (2001)."Addressing the Digital Divide" in Online Information Review, Vol. 25, No. 5, 311-320.

Davadason, E. (2011). "Policy Chaos Over Migrant Workers in Malaysia," East Asia Forum, 11 January 2011, [Online], [Retrieved February 02, 2011],http://www.eastasiaforum.org/201 1/01/11/policy-chaos-over-migrantworkers-in-malaysia/.

Depkominfo (2002). 'The Implementation of ICT Development in Indonesia,' Presentation held on the 2nd Meeting on Asia-Pacific Initiative for the Information Societies, Brunei Darussalam, 5-9 August 2002, Directorate General of Posts and Telecommunications, The Ministry of Communications of the Republic of Indonesia, [Online], [Retrieved June 10, 2008],

http://unpan1.un.org/intradoc/groups/pu blic/documents/APCITY/UNPAN006373.p df.

ESCAP (2006). Guidebook on Developing Community E-Centres in Rural Areas: Based on the Malaysian Experience, New York: United Nations. [Online], [Accessed 27 August 2008], http://www.unescap.org/icstd/Pubs/ICTA S_cec_guidebook.pdf.

Evers, H.-D. \& Gerke, S. (2005). 'Closing the Digital Divide: Southeast Asia 's Path towards a Knowledge Society,' Working Paper No. 1, ZEF Working Paper Series, Bonn: Center for Development Research, [Online], [Retrieved May 04, 2008], http://www.zef.de/fileadmin/webfiles/do wnloads/zef_wp/zef_wp1_evers-gerke.pdf.

Fraser, C. \& Estrada, S. R. (2001)."Community Radio Handbook," Paris: UNESCO [Online], [Retrieved 20 June 2008],

http://unesdoc.unesco.org/images/0012/ 001245/124595e.pdf.

Hofstede, G. (1997). Cultures and Organizations: Software of the Mind, New York: McGraw-Hill.

HRW (2004). "Help Wanted: Abuses against Female Migrant Domestic Workers in Indonesia and Malaysia," Human Rights Watch Vol. 16, No. 9 (C). [Online], [Retrieved February 16, 2008], http://hrw.org/reports/2004/indonesia07 04/indonesia0704full.pdf. 
ILO (2006). 'Indonesian Migrant Domestic Workers, Long Way Home,' [Video: DVD], Jakarta: International Labour Office.

ILO (2008). "Combating Forced Labour and Trafficking of Indonesian Migrant Workers (Phase I)". Jakarta: International Labour Office.

Itim (2008). Geert Hofstede ${ }^{\mathrm{TM}}$ Cultural Dimensions: Indonesia, [Online], [Retrieved 21 August 2008], http://www.geerthofstede.com/hofstede_indonesia.shtm.

Immigration Department of Malaysia (2010)."Foreign Domestic Helper - SyaratSyarat Kelayakan Pembantu Rumah Asing (PRA)," [Online], [Retrieved February 13, 2010],

http://www.imi.gov.my/index.php/en/for eign-domestic-helper.

Jakarta Post (2011). "RI Highly Dependent on Mobile Internet," Jakarta Post, 12/07/2011[Accessed 7th November 2011],

http://www.thejakartapost.com/news/20 11/07/12/ri-highly-dependent-mobileinternet.html

Kaur, A. (2004). "Mobility, Labour Mobilisation and Border Controls: Indonesian Labour Migration to Malaysia Since 1900," Paper presented to the 15th Biennial Conference of the Asian Studies Association of Australia in Canberra 29 June-2 July 2004, [Online], [Retrieved September 19, 2007], http://coombs.anu.edu.au/SpecialProj/AS AA/biennial-conference/2004/Kaur-AASAA2004.pdf.

Lyons, L. T. (2005). "Embodying Transnationalism: The Making of the Indonesian Maid" in Lorek-Jezinska, E. and Wieckowska, K. (Eds.) Corporeal inscriptions: Representations of the Body in Cultural and Literary Texts and Practices, Uniwersytet Mikolaja Kopernika: Nicolas Copernicus University Press, Torun, Poland, pp. 171-185, [Online], [Retrieved March 16, 2008], http://ro.uow.edu.au/cgi/viewcontent.cgi? article $=1089 \&$ context $=$ artspapers.
MFA (2006). 'Migrants and Rights in Malaysia,' [Online], [Retrieved August 07, 2008],

http://www.mfasia.org/mfaStatements/St atement46-

MigrantsAndRightsInMalaysia.html

Nainggolan, A. E. (2007). 'Buku Saku Tenaga Kerja Indonesia,' Depok: Tabloid Dunia Tenaga Kerja Indonesia.

Nasir, A., Tanesia, A., Prakoso, I \& Amri, M. (2007).'Media Rakyat: Mengorganisasi Diri Melalui Informasi,' Yogyakarta, Indonesia: Combine Resource Institution.

PDOP (2008). 'Interview with Staff of the Pre-Departure Orientation Program in Jakarta,' Indonesia, 15th May 2008.

Raharto, A. (2002). "Indonesian Female Labour Migrants: Experiences Working Overseas (a Case Study among Returned Migrants in West Java)," Bangkok: Paper presented at the 2002 IUSSP Regional Population Conference on Southeast Asia's Population in a Changing Asian Context, 1013 June, [Online], [Retrieved April 05, 2008],

http://www.iussp.org/Bangkok2002/S10A Raharto.pdf.

Romdiati, H., Noveria, M. \& Bandiyono, S. (Eds.) (2002). 'Kebutuhan Informasi Bagi Tenaga Kerja Migran Indonesia: Studi Kasus di Propinsi Jawa Barat,' Kalimantan Timur dan Riau, Jakarta: Pusat Penelitian Kependudukan - Lembaga Ilmu Pengetahuan Indonesia (PPK-LIPI).

Servon, L. J. (2002). Bridging the Digital Divide, Technology, Community, and Public Policy, Information Age Series, Oxford: Blackwell Publishing.

Stephenson, F. (1996). "HEDS Up in Indonesia," Florida State University's Research in Review, Winter 1996 Issue [Online], [Retrieved 20 August 2008], http://www.rinr.fsu.edu/winter96/feature s/heds.html.

Tenaganita (2005). Breaking Labour [DVD]. Kuala Lumpur: Tenaganita. 
Tenaganita (2008). 'Interview with Staff of Tenaganita,' 8th August 2008.

UNIMAS (2005). 'ICT for Rural Development: The eBario Experience,' PowerPoint Presentation held at the Regional Meeting on Effective Design and Delivery of Rural Community ICT Services," Kuala Lumpur, 28-30 November 2005. [Online], [Retrieved 27 August 2008], http://www.unescap.org/icstd/application s/projects/Malaysia_CeC/docs/ebarioUnescap-v3.ppt,

UNFPA (2006). 'A Passage to Hope Women and International Migration, The Good, The Bad, The Promising: Migration in the 21st Century' [Online], [Retrieved 04 August 2008], http://www.unfpa.org/swp/2006/english /chapter_1/burden_or_boon.html.

WAO (2008). 'Interview with Staff of Women's Aid Organisation,' 4th August 2008.

Wawa, J. E. (2005). 'Ironi Pahlawan Devisa. Kisah Tenaga Kerja Indonesia dalam Laporan Jurnalistik,' Jakarta: Kompas.

Werning, R. \& Fuhrmann, K. (2008). Schattenspiele [Radio Documentary]. SWR2 Wissen, 22.02.2008. Stuttgart: SWR2.

Whatt, C. K. (2004). Foreign maids, The Complete Handbook for Employers and Maid Agencies, Singapore: SNP Editions.

Zamani, A. (2002). The Malay Ideals, Kuala Lumpur: Golden Books Centre Sdn. Bhd 